\title{
Oswald Pirow's Five-Year Plan for the Reorganisation of the Union Defence Force, 1933-1939
}

\section{Johan Ellis}

\section{Introduction}

The Union Defence Force (UDF) experienced constant changes in its size and organisation during the first few decades of existence since being established on 1 July 1912. During the First World War it's size increased, ${ }^{2}$ only to decrease again with demobilisation after the War. Another upward trend was experienced over the period 1922-1926, with the first line of defence increasing in number during 1924 from 10000 to $25000 .^{3}$ The Depression of 1929-1933 stopped this tendency, resulting in the disbandment of no less than 49 Active Citizen Force (ACF) units.

During 1933 however, it became clear that the Depression was drawing to an end and economic revival within South Africa became a reality. At the same time, that is during 1933, the top management within the Ministry of Defence as well as the UDF were replaced. Advocate Oswald Pirow was appoin ted as Minister of Defence and Maj. Gen. A.J.E. Brink as Secretary of Defence. Sir Pierre van

The content of this paper was obtained primarily from SANDF Archival Depot. This does however include the communication between Advocate Oswald Pirow as Minister and Maj. Gen A.J.E. Brink as Secretary of Defence with Sir Pierre van Ryneveld. As such, it is possible that the role and the processes within of the Union Defence Force is over-emphasised, while that of the other role players like Pirow and Brink are underplayed.

2 South African National Defence Force Archives Repository, Pretoria (hereinafter SANDFAR), Diverse (Group 1), File (GS Defence Council Meeting 15/6/1935), Notes on Ministers outline of Defence Policy. Defence Council Meeting, 15 Jun 1935 , p 1.

SADFAR, CGS (Group 1), File 35/1 (Composition: Force of 25 000), Memorandum on the necessity of a Force of 25000 Citizens to safeguard the interests of the Union, pp 1-2.

A.C. Lillie, "The Origin and development of the South African Army", Militaria, Vol. 12/2 1982, pp 12-14. 
Ryneveld was appointed as Chief of the General Staff (CGS). ${ }^{5}$ The expectation of economic prosperity urged the new top management, to consider the reorganisation and expansion of the UDF. These expectations led to an announcement to Cabinet by Oswald Pirow on 16 October 1933 of his intend to re-evaluate the Union's security situation and to implement the expected reorganisation resulting from the re-evaluation by means of a five-year plan. ${ }^{6}$ The five-year plan was announced in Parliament on 2 May 1934 and with time, became known as "Oswald Pirow's Fiveyear Plan". On studying the sources however it is clear that Pierre van Reyneveld and not Oswald Pirow was the true driving force behind the plan. Pierre van Reyneveld as CGS however was responsible for most of the planing and for drawing up the plan. As Minister of Defence Oswald Pirow was the public figure with whom the plan was associated, hence the name: "Oswald Pirow's Five-year Plan".

It is the intention with this paper to analyse the Five-year Plan developed under the guidance of Oswald Pirow against the backdrop of the Union Defence Policy at the time. In doing this the paper will elaborate on some of the factors that influenced the Five-year Plan, secondly on the Plan itself, and thirdly only on the implementation of the plan within the SA Army. In this the territorial reorganisation will be referred to, the reorganisation of the ACF with specific reference to the Infantry Regiments. Restricting the discussion on the implementation of the plan to the reorganisation of the SA Army is out of necessity. Similar frustrations as will be seen in the implementation of the plan within the Army, was also present in the implementation with regard to the air and naval capacities of the UDF.

\section{Union Defence Policy}

The Union Defence Policy as formulated during 1926, and remained unchanged during the period under discussion. It contained a quadripartite aim:

- The prevention and suppression of internal unrest.

- The military training of a part of the young men of the Union.

- The protection of the union against an external threat.

- Considering preparations for an expedition force should the Union become involved in a European War.

From this it is clear that the prevention and suppression of internal unrest enjoyed a high priority within the Union. Although the policy did not state it as such, this aim was interpreted as referring to black risings. This is clear from van

Anon. "Die Unieverdedigingsmag op die Vooraand van die Tweede Wêreldoorlog (1934-1939)", Militaria, 1976, pp 25.

SANDFAR, Diverse (Group 1), File (Sir P. van Ryneveld - Secret Documents: Reorganisation 1933; Org RAF; Visit to London; RAAF Org), Attached document to letter from the Assistant Private Secretary of Defence to P. van Ryneveld, 3 Sep 1934, p 1. 
Reyneveld's comments as part of his discussion on the re-evaluation of the Union's security situation. In this he states that the last serious threat in this regard was the Bondelswart Rising of 1922 . He then continues by explaining that even if the blacks in Basotuland, Transkei, Zululand or Swaziland should rise against the Union, contingency plans were in place to suppress such a threat. ${ }^{7}$ He therefore regarded this aim as addressed, not justifying further attention.

With regards to the second aim, that of the military training of a part of the young men of the Union, there was also not much more to be done. The Special Service Battalions (SSB) aimed at providing military training and other skills to specifically white Afrikaans speaking young men of the Union existed and was succeeding in its intention. The potential of the SSB's however was realised and as part of the Five-year Plan, the Battalions was seen as a source of able-bodied men to be trained as non-commissioned officers (NCO) for the National Reserve. ${ }^{8}$

With the first two priorities identified in the Defence Policy addressed it was now possible to focus on and work towards the last two aims identified in the Defence Policy.

The first of these was the protection of the Union against an external threat. In his re-evaluation of the Unions security situation Pierre van Reyneveld identified two possible directions from which a threat can originate. Since the Unions borders included both maritime and continental boundaries, these were a maritime threat, in other words one of the big powers could make a coastal assault on the Union or, alternatively the Union could be threatened by means of an attack from the north over land.

\section{- $\quad$ Maritime Threat.}

Van Reyneveld accepted that the British Navy would be willing and able to protect the Union against attacks from any opponent. ${ }^{9}$ The precondition to this however was early warning in order to enable the British Navy to deploy toward

SADFAR, CGS (Group 1), File 35/1 (Composition: Force of 25 000), Memorandum on the necessity of a Force of 25000 Citizens to safeguard the interests of the Union, p 1.

Hansard, Part 23, col 3347.

Compare SADFAR, CGS (Group 2) File (CGS 96 Re-organisation UDF), Volume II, Suffix 1, South African Defence Policy, 20 Sep 1933, pp 1-2; R.M. Kennedy: The Rise and Fall of British Naval Mastery, p 285 and SANDFAR, Diverse (Group 1), File (Sir P. van Ryneveld - Secret Documents: Reorganisation 1933; Org RAF; Visit to London; RAAF Org), Assistant Private Secretary of Defence to P. van Ryneveld, 3 Sep 1934, p 3. 
South Africa or to cut of the attacking navy on sea. ${ }^{10}$ Since early warning was not always possible, it was concluded that the Union must at least possess the ability to delay the attacking navy to such an extend that sufficient time will be won to enable the British Navy to mobilise and to redeploy towards South African waters.

The cost involved in procuring the ships necessary to achieve this however simply was too high. Given the strategic importance of South Africa's harbours with regard to the sea-route to India, maintaining the ability to secure the harbours against mines by means of mine-sweepers was accepted as the most feasible solution. ${ }^{11}$

The only alternative therefore was to strengthen the existing coastal defences. ${ }^{12}$ Two problem w.r.t. the existing Coastal Garrisons were to be addressed:

The first being that the current Coastal Garrisons were static defences protecting only South Africa's harbours. Although these were regarded as necessary, it was decided that that the existing garrisons were to be supplemented with mobile artillery and infantry units. $^{13}$ These units would then be in a position to serve a dual purpose since it could be deployed as coastal defence or as part of a land force.

The second problem related to the range of the coastal batteries or artillery, especially against cruisers. Cruisers at the time were equipped with gunnery with a range of $\pm 27,5$ kilometres. That implied that the cruisers could fire on targets while still out of sight. In addition to this cruisers also carried one aircraft used to direct fire and with a limited ability to deliver bombs. The implication of this was that the coastal batteries were extremely vulnerable against cruisers. Van Reyneveld,

SANDFAR, Diverse (Group 1), File (Sir P. van Ryneveld - Secret Documents: Reorganisation 1933; Org RAF; Visit to London; RAAF Org), Assistant Private Secretary of Defence to P. van Ryneveld, 3 Sep 1934, p 2.

SANDFAR, Diverse (Group 1), File (Sir P. van Ryneveld - Secret Documents: Reorganisation 1933; Org RAF; Visit to London; RAAF Org), Assistant Private Secretary of Defence to P. van Ryneveld, 3 Sep 1934, p 3.

Ibid., p 4.

13 SANDFAR, Diverse (Group 1), File (Sir P. van Ryneveld - Secret Documents: Reorganisation 1933; Org RAF; Visit to London; RAAF Org), Assistant Private Secretary of Defence to P. van Ryneveld, 3 Sep 1934, p 3. 
being an Air Force man himself, saw aircraft as the solution to this. Aircraft could not only be used against surface ships, but he regarded it as just as effective against submarines. In addition aircraft were highly mobile and could be used in a number of different roles, including assistance to the Army, in a land battle or during internal unrest and for numerous other support tasks. ${ }^{14}$

- $\quad$ Continental Threat.

W.r.t. a continental threat Van Reyneveld, in his reevaluation, states that he was concerned about the possibility of an invasion by the black masses to the north of the Union. $\mathrm{He}$ reiterated his position on this by arguing that it is essential to be prepared against such a threat since the "... maintenance and supremacy of our white civilisation..." ${ }^{15}$ depended on this. $\mathrm{He}$ further supported his argument by expressing his concern about what he referred to as the policies of France, Belgium and Portugal to arm blacks in their colonies in an attempt to strengthen their own military capabilities in Africa. This he argued would supply the weapons to those blacks in southern Africa that were constantly searching for methods to free themselves from European domination. A highly mobile, compact force with superior weapons was regarded as the only feasible solution to address such a threat.

Within this line of thinking, van Reyneveld argued that the black masses from Africa would only be able to launch an attack on the Union if they were supported by the European colonial powers, and then only as part of a bigger European war. In such a war, he argued, the European power would only be able to open an additional front in southern Africa when Britain had been removed from Africa north of the Sahara. The most sensible way of protecting South Africa from this perspective was to assist Britain in North Africa, should a European war transpire. In following this line of thought, van Reyneveld effectively justified addressing the fourth aim stipulated in the Defence Policy, namely that of considering preparations for an expedition force, should the Union become involved in an European War. The type of expedition force envisaged for assistance to Great Britain in North Africa show great similarities to that necessary for protecting a continental assault on the Union, namely a highly mobile, compact South African Defence Policy, 20 Sep 1933, pp 7-9.

Ibid., pp 2-4. 
force with superior weapons. One more condition was however stated, that was the necessity of air support. ${ }^{16}$

\section{Other Factors Influencing The Plan} numerous sources:

Apart from the arguments mentioned, pressure was exerted from

- Maj. Gen. A.J.E. Brink. Brink, when still the CGS, during 1924 emphasised the fact that increasing the size of the first line of defence to 25,000 men was unsatisfactory. According to him, the number simply was insufficient to delay an invading force long enough for the mobilisation of the NR. ${ }^{17}$ As Secretary of Defence he now was in a position to influence decisions, to a certain extend behind the scenes.

- $\quad$ The Depression. As already mentioned, the preparedness of the ACF was seriously affected by the Depressions. This inefficiency was clearly realised within South Africa.

elaboration.

- $\quad$ British Expectations. In this regard two aspects justifies

$>\quad$ Increasing the size of the UDF. After the $1^{\text {st }}$ World War, and more specifically under the auspices of the Geneva Convention, the European powers were constantly pressured to reduce the size of their military, both in terms of size and weapons. This process gained renewed momentum during the 1920's. In spite of numerous meetings in this regard, the nations involved could not come to an agreement, and by 1929 it seemed as if the negotiations would come to an unresolved end. Britain now came forward with the proposal that the size of a countries military must be restricted to a percentage of it population. ${ }^{18}$ The implication of this was that the defence forces of most European nations were to big, but that of the colonies was still too small, especially when blacks were included in the total number of the population. In a letter to Brink, the Imperial War Office suggested that this should be used as an argument for increasing the size of the UDF. ${ }^{19}$ This

Ibid., pp 5-6.

SADFAR, CGS (Group 1), File 35/1 (Composition: Force of 25000 ), Memorandum on the necessity of a Force of 25000 Citizens to safeguard the interests of the Union, p 2 .

His Britannic Majesty's Government, Imperial Conference 1930: Reduction and Limitations of Armaments, Copy no. 33, pp 1-6.

SADFAR, Diverse (Group 1), File CGS 25/1 (Periodic Letters - CGS + C1GS, gin), Periodic letter No 2/1933, From the War Office in London to Maj. Gen. A.J.E. Brink, 26 Apr 1933, pp 2-3. 
probably was the reason for France's, Portugal's and Belgium's policy of arming blacks in their colonies. In South Africa's case however, within the mindset of maintaining white superiority, blacks were intentionally excluded, resulting in a white UDF and the increased militarisation of the white South African community.

$>\quad$ Conflicting messages from Britain. In formal communication between the British Government and South Africa it is clearly stated that the nature and extend of assistance that Britain would expect from South Africa will entirely depend on the decision of the South African Government. ${ }^{20}$ However, at the Imperial Conferences of both 1930 and 1933 it was clearly communicated during meetings of for example the "Committee of Experts on the Fighting Services" that the preparedness of the UDF must improve in order for South Africa to be able to fulfil its responsibilities towards Britain. ${ }^{21}$ It is clear that Pirow accepted this responsibility since, on 16 October 1933 he clearly stated to the Cabinet that the Union would have to improve its ability to assist Britain in war. ${ }^{22}$

\section{The Objectives Of Reorganisation}

From all of this three organisational objectives were clear:

- The Army must develop the ability to deploy a compact, highly mobile force with superior weapons to be deployed anywhere in Africa for both the defence of South Africa and assistance to Britain.

- The Naval Service must be able to protect the Unions important harbours against mines and the rest of the maritime border by delaying any assault long enough to allow time for the British Navy to arrive in South African waters.

- The Air Force must develop the ability to support the Army in a war anywhere in Africa and the Naval Service in the protection of the Unions maritime border.

SANDFAR, Diverse (Group 1), File (Sir P. van Ryneveld - Secret Documents: Reorganisation 1933; Org RAF; Visit to London; RAAF Org), The necessity for the maintenance of Defence Forces in the Union of South Africa, p 3.

SADFAR, CGS (Group 1), File G8/10 (Imperial Conference: 1930), Committee of experts on the Fighting Services, Draft Report, Copy no 6 and SANDFAR, Diverse (Group 1), File (Sir P. van Ryneveld - Secret Documents: Reorganisation 1933; Org RAF; Visit to London; RAAF Org), No Suffix number, The necessity for the maintenance of Defence Forces in the Union of South Africa, p 3. 
Ten days before the intention to reorganise the UDF was made known to Cabinet by Pirow, van Reyneveld had already forwarded his re-evaluation and intentions to the Adjutant General and the Quartermaster General for their comments. ${ }^{23}$ Before any of these objectives could be addressed the method in which the envisaged personnel expansions were to be achieved had to be considered.

\section{The Personnel Reorganisation Of The Udf}

The personnel of the UFD were employed in one of three systems, namely the Permanent Force (PF), the ACF and the National Reserve (NR). The NR in tum consisted of the Defence Rifle Associations and the Cadets. These systems implied separate units and therefore worked against unity in the UDF. ${ }^{24}$ Although the systems of employment were maintained, units were to be reorganised in an attempt to obtain larger unity in the UDF.

The Permanent Force. PF personnel were to be redeployed to function as the infrastructure or core around which active and reserve units were to function. With this in mind, PF personnel were to be employed in Headquarters ${ }^{25}$ for the training of officers and NCO's, ${ }^{26}$ and in key positions in for example the Air Force ${ }^{27}$ and the Artillery. ${ }^{28}$ As "infrastructure" the PF personnel were responsible for the organisation, training and mobilisation of specifically the ACF units and to a lesser extend the NR.

The Active Citizen Force. Members from the ACF were to serve, as they did in 1933, amongst other in artillery- and infantry units in the Army, as pilots and maintenance personnel in the Air Force and in the coastal batteries of the Naval Services. ${ }^{29}$ Active service however was to based on a three-year rotation. Within

SADFAR, CGS (Group 2) File (CGS 96 Re-organisation UDF), Volume II, Suffix 2, U.D.F.: Minute by P. van Ryneveld with regard to the U.D. F. Re-organisation, 6 Oct 1933, pp 1-2.

SANDFAR, Diverse (Group 1), File (Sir P. van Ryneveld - Secret Documents: Reorganisation 1933; Org RAF; Visit to London; RAAF Org), Assistant Private Secretary of Defence to P. van Ryneveld, 3 Sep 1934, p 8.

SADFAR, AG(3) 154, File AG (3) 154/51/5/0 UDF - 1933 Reorganisation General Details), Suffix 2 Memorandum attached to Letter by P. Van Ryneveld to Officers Commanding the Commands, 10 Nov 1933, pp 1-2.

SANDFAR, Diverse (Group 1), File (Sir P. van Ryneveld - Secret Documents: Reorganisation 1933; Org RAF; Visit to London; RAAF Org), South African Defence Policy, p 7.

SADFAR, AG(3) 154, File AG (3) 154/51/5/0 UDF - 1933 Reorganisation General Details), Suffix 2 Memorandum attached to Letter by P. van Ryneveld to Officers Commanding the Commands, 10 Nov 1933, p 1.

Ibid., p 3 .

Ibid., pp 3-4. 
the $\mathrm{ACF}$ regiments, that is the infantry units (as example), the reorganisation worked as follow:

In 1933 most of the sixteen ACF Regiments, with the exception of a few in Natal, were urban-based units. As part of the reorganisation the number of units were to increase by eight to twenty four. Twelve of which were to be urban-based units and twelve outside of the major urban centres. ${ }^{30}$ The units were to be officially established on 1 April 1934 (before Pirow's announcement in Parliament $)^{31}$ and to recruit two companies within the first two years. ${ }^{32}$ Each year thereafter the units were to recruit the personnel for a third company, while the first company was to become the units reserve. In the following year, the reserve would be transferred to the NR. ${ }^{33}$ This system implied that PF personnel would man the Regiments on a permanent basis. The PF personnel would recruit one company per year to be trained on a part-time basis, while another company is available on active service and the third company as in reserve. On a yearly basis each company would move on to its next stage of preparedness, until after three years, it becomes a source of manpower for the NR.

The National Reserve. Over the five-year period of the plan, the NR with reference to the Defence Rifle Associations were to be increased to 120000 men. $^{34}$ Officers from the ACF companies who had completed their term in the ACF were to be recruited as officers for the NR, ${ }^{35}$ while NCO's were to be recruited from those who had completed their term in the ACF or the SSB's. ${ }^{36}$ The men who were to serve in the NR were the serving members in the Defence Rifle Associations in 1933, the men who had completed their term in the ACF and the Cadets of whom

SANDFAR, Diverse (Group 1), File (Sir P. van Ryneveld - Secret Documents: Reorganisation 1933; Org RAF; Visit to London; RAAF Org), Assistant Private Secretary of Defence to P, van Ryneveld, 3 Sep 1934, p 8 and Hansard, Part 23, col 3346.

SANDFAR, AG(3) 154, File AG (3) 154/51/5/0 UDF - 1933 Reorganisation General Details), Suffix 3, Director Military Operations and Training to Officers Commanding Commands, 25 Nov 1933, p 1.

SADFAR, AG(3) 154, File AG (3) 154/51/5/0 UDF - 1933 Reorganisation General Details), Suffix 2 P. van Ryneveld to Officers Commanding the Commands, 10 Nov 1933, p 4.

SADFAR, AG(3) 154, File AG (3) 154/51/5/0 UDF - 1933 Reorganisation General Details), Suffix 3, Director Military Operations and Training to Officers Commanding Commands, 25 Nov 1933, p 1.

Hansard, Part 23, col 3349.

Ibid., p 3346.

Ibid., p 3347. 
approximately 20,000 youths between the ages of 14 and 17 were members. ${ }^{37}$ The preparedness of these men would then be maintained by means of regular retraining. $^{38}$

A system within which PF members were to function as the backbone of the UDF was envisioned. They, together with the serving ACF members would then function as the first line of defence of the Union. The NR, with an additional 120,000 men, were organised as exactly that, a reserve to be mobilised as second line of defence in case war.

\section{Reorganisation Of The Army}

\section{The Territorial Reorganisation}

South Africa was militarily divided into six districts by 1933. As part of the initial planing for the reorganisation of the UDF it was decided to organise the UDF into five Commands (Kommandemente), one per province, that is the Transvaal, Orange Free State, Natal and the Cape, and one at Roberts Heights, the current Taba Tswane. ${ }^{39}$ After some deliberation however it was decided to divide the Cape Command into two, namely that of the Cape Command and Eastern Province Command. With the assumption that the plan would be approved by Parliament, the six commanders were appointed on 10 November $1933{ }^{40}$ They were provided with the preliminary borders for the Commands on 11 December 1933. In the letter to the commanders they were tasked to identify possible sites for the respective units envisaged in their areas. ${ }^{41}$ The six Commands were officially established through publication in the Government Gazette on 9 March 1934, almost two months before Pirow's announcement in Parliament. ${ }^{42}$

Each Command, with the exception of Roberts Height Command, had its own Training Depot. With the exception of the training for officers and NCO's, that was provided at the Military College at Roberts Heights, the Commands were to provide for all the training applicable on the Units under it's command at these Training Depots. In addition to its normal responsibilities, Cape Command was also

Ibid., p 3344.

Ibid., p 3349.

SADFAR, CGS (Group 2), File CGS 96 (Reorganisation of the UDF, Volume II), Suffix 2, P. van Ryneveld on the reorganisation of the U.D.F., Oct 1933, p 1.

SADFAR, AG(3) 154, File AG (3) 154/51/5/0 UDF - 1933 Reorganisation General Details), Suffix 2 P. van Ryneveld to Officers Commanding the Commands, 10 Nov 1933, p 1.

SADFAR, CGS (Group 2), File CGS 96 (Reorganisation of the UDF, Volume II), Suffix 20, Director of Military Operations and Training, 11 Dec 1933.

The Union of South Africa, Government Gazette, Volume XCV, no 2177, 9 Mar 1934, p 671. 
responsible for co-ordinating the coastal defences of the Union. ${ }^{43}$ While the reorganisation of the UDF would be co-ordinated from Defence HQ, each Command was responsible for the reorganisation in its own area.

\section{The Active Citizen Force Infantry Regiments}

As already mentioned, the ACF Infantry Regiments were to increase by eight to twenty-four of which twelve were to be urban based and twelve based in the countryside. The new Regiments were Delarey Regiment in the Western Transvaal, Botha Regiment in the Northern and Eastern Transvaal, Steyn Regiment in Bloenfontein, De Wet Regiment in the Northern Free State and Louw Wepener Regiment in the Southern Free State. The other two new regiments were to be established in the Cape and Eastern Province respectively. ${ }^{44}$ This would bring the total number of regiments to twenty-four of which seven were in the Transvaal, four in the Orange free State, five in Natal and four respectively in the Cape and Eastern Province. The twenty-four regiments were further organised into six Brigades based on the territorial Commands. ${ }^{45}$ This implied that, with the exception of Tranvaal Command where two Brigades were to be stationed, each of the other Commands (Roberts Heights excluded) had one Brigade under command.

The establishment of a compact Army with modern weapons as stipulated in the original policy documents now had to materialise in the organisation of the regiments. For this purpose the internal organisation of all the regiments with the exception of Durban Light Infantry-, the Transvaal Scottish-, and Pretoria Regiments changed to the following organisation:

SADFAR, CGS (Group 2), File CGS 96 (Reorganisation of the UDF, Volume II), Suffix 2, Memorandum attached to letter by P. van Ryneveld on the reorganisation of the U.D.F., Oct 1933, p 1.

Hansard, Part 23, pp. 3345-3346.

SADFAR, AG(3) 154, File AG (3) 154/51/5/0 UDF - 1933 Reorganisation General Details), Suffix 2 Memorandum attached to Letter by P. Van Reyneveld to Officers Commanding the Commands, 10 Nov 1933, p 4. 


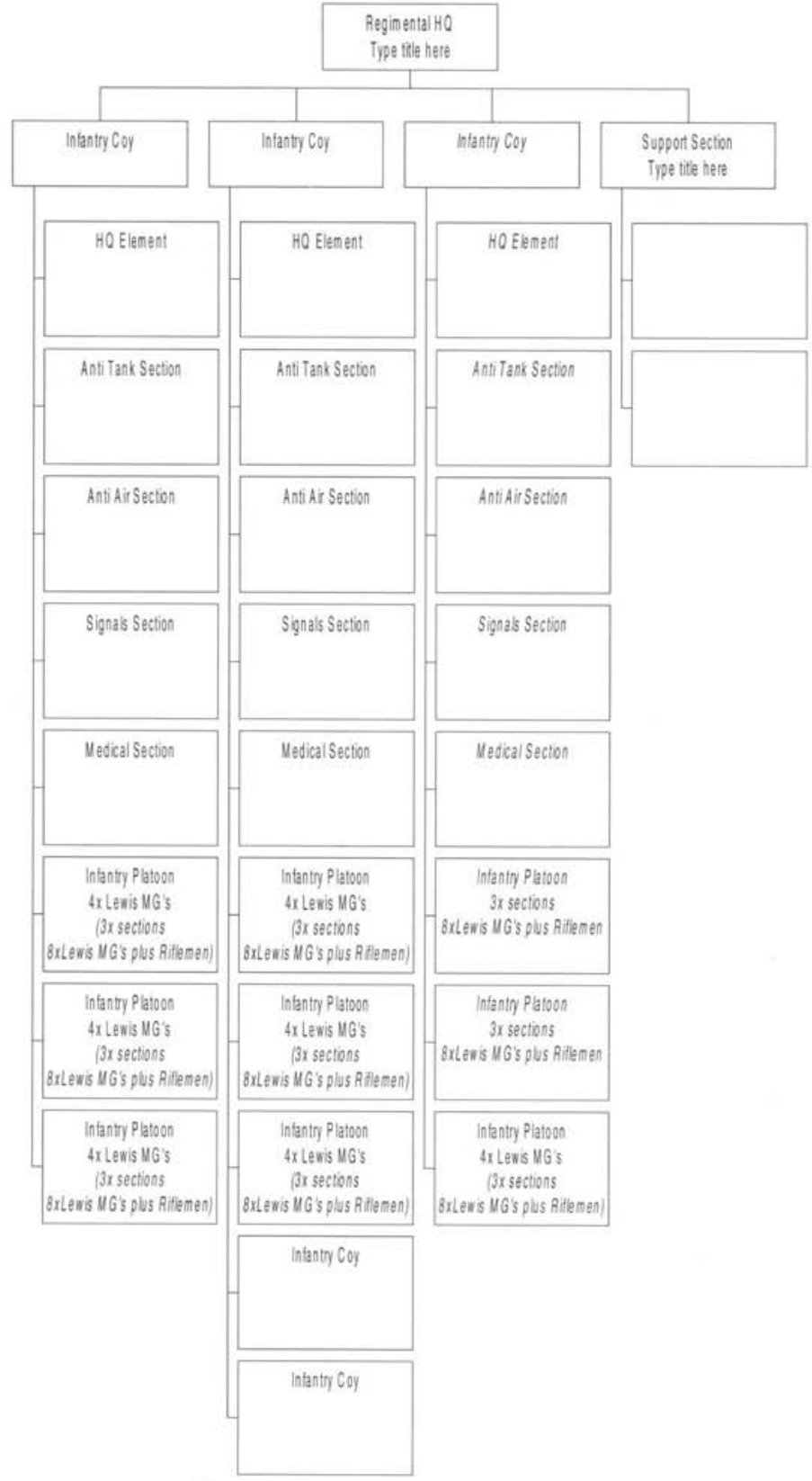

Figure $1^{46}$ 
Effecting the internal reorganisation of the Regiments was relatively easy, but providing the weapons therefore proved a different kettle of fish.

- Vickers Machineguns. Of the twelve Vickers Mg's envisaged in each Regiment, only six was available. To overcome this shortage six Vickers Mg's were issued to each of the Training Depots. Through this arrangement the necessary twelve Mg's were available when the Regiment reported to the Training Depots for training. ${ }^{47}$

- Lewis Machineguns. No Lewis Mg's were issued to the Regiments since only a small number of the weapons could be procured. These were sent to the respective Training Depots to be available for training. ${ }^{48}$

- Mortars. Almost no mortars were available, therefore it was planned that when mortars should become available, in terms of distribution, it would be dealt with in the same way as with the Vickers Mg's. ${ }^{49}$

The implication of this was that although the regiments were reorganised with high expectation they had to live under a situation of constant disappointment since the weapons were simply not forthcoming.

Even the hope expressed by Pirow in his announcement on 2 May 1934 to start with the manufacturing of weapons in South Africa had to end in disappointment. The Union simply did not possess the necessary technological skills. ${ }^{50} \quad$ The Union therefore remained dependant on Great Britain for its armament, and Britain's priority was to supply in her own needs first. ${ }^{51}$ At the most South Africa could expect to procure Britain's obsolete weapons.

This general lack of support weapons resulted in several more organisational changes:

- By October 1945 it was decided to concentrate the support weapons of the regiments into a separate support battalion. With this change the number of companies within the regiments were also increased to four, while the sections within the platoons became rifle sections. The idea of four Mg's in the platoon was maintained, but this time with the precondition "if available". ${ }^{2}$

- Before these changes could be effected, it was further decided that since the antitank weapons were spread to thinly, an antitank brigade, the seventh Brigade was established. ${ }^{5}$

- In May 1936 it was decided that the rifle regiments in future would be known as "Light Regiments" while the support regiments were to be known as "Heavy Regiments". ${ }^{54}$ The peace-time strength of these 
regiments were to be 269 in a Antitank Regiment, 378 for a Heavy Regiment and 356 for a Light Regiment. ${ }^{55}$

These changes however still did not solve the problems w.r.t. the availability of weapons. The general lack of support weapons therefore resulted in both the Antitank and Mortar companies receiving training with the Vickers $\mathrm{Mg}$, while the Light regiments continued training with the available Lewis Mg's, awaiting the arrival of the Bren Mg's. ${ }^{56}$

By December 1937, a Year and a half after the implementation of these changes, the criticism and reports from the Commands against the 1936 changes reached a climax. It was argued that the 1934 organisation provided the best potential wrt manoeuvrability, mobility and sustainability. This resulted in reverting back to the 1934 structure. ${ }^{57}$

As the international security situation changed during the late 1930's it as decided to experiment with different organisations in an attempt to achieve a balanced force with the ability to conduct independent operations. For this reason, an experimental "Bush Brigade-group" with Battalion-groups was established in March $1938 .^{58}$ This implied that a unit or Brigade could be established for a specific independent task. After completion of the task it would then revert to its original structure. In accordance with this the number of Infantry Brigade increased to nine on 1 July 1938. This however was a wartime structure and all the regiments remained under command of the Command in which area it resided. ${ }^{59}$

During the same year (1938) the nine brigades were further organised into three Divisions. Of these two divisions were to function as the "Mobile Field Force", in other words SA's offensive capability while the third division would be responsible for the protection of SA itself, that is in case of war.

The problem wrt armament was still not solved. In August 1938 the Chief of the Imperial General Staff informed Pierre van Ryneveld in a letter that the British Army was close to the point of saturation and that SA can forward it's requirement in the hope that delivery would soon be made. ${ }^{60}$ By September 1939 however the problem still persisted. The changing security situation in Europe simply did not allow Britain to supply weapons to SA, her own escalating requirements had to be satisfied first.

\section{Conclusion}

At the end of the five-year period thus the Infantry organisation of the SA Army, at least on paper and in terms of personnel were in a better position than they were in 1933. In terms of support weapons, namely mortars, Mg's and Antitank weapons, the Units were totally under equipped. A similar situation existed with regard to SA's air and naval abilities.

Although the reorganisation thus did not comply with the objectives as indicated in the Five-Year Plan, the UDF in general was on a higher level of 